\title{
Antimicrobial Activity of the Crude Extract Derived from Streptomyces spp. Associated with Sponges
}

\author{
S. Parimala ${ }^{1 *}$, M. Kandhasamy ${ }^{*}$ and P.S. Chinnasamy ${ }^{1}$ \\ PG and Research Department of Botany, Government Arts College (Autonomous), \\ Karur - 639 005, India \\ *Corresponding author
}

\section{A B S T R A C T}

Keywords

Sponges,

Actinomycetes,

Human pathogens,

Crude extract,

Antibacterial

activity, Antifungal

activity, Minimum

inhibitory

concentration

Article Info

Accepted:

08 July 2018

Available Online:

10 August 2018

The objective of the present investigation was to isolate and identify the antimicrobial activity showing actinomycetes associated with sponges. Sponges such as Acanthella klethra, Theonella cylendrica, Helicona sp., Auletta sp., and Callyspongia sp. were collected at Sangumal, in Rameswaram island, Ramanathapuram District, Tamil Nadu, India. Isolates of 22 actinomycetes were isolated from sponges. Isolates No. 16 showed high antibacterial and antifungal activity and the isolate was identified as Streptomyces sp. Antibacterial and antifungal activity was determined by agar diffusion method and Minimum Inhibitory Concentration (MIC) of the extract was determined by two fold dilution method using microstate plate. The study showed that fungal pathogens were more susceptible to the extract than bacteria. Among bacterial pathogens, Escherichia coli was more susceptible to the extract, followed by $P$. aeruginosa, Bacillus subtilis, and Staphylococcus aureus and their growth were inhibited at the concentration of $2 \mathrm{mg} / \mathrm{ml}$. Other bacterial pathogens were resistant to the crude extract derived from culture broth extract of Streptomyces sp. Fungal pathogens such as Candida albicans, Zynomonas sp., Aspergillus niger and A. rutus were susceptible to the extract and the MIC for the fungal pathogens ranged between $0.015 \mathrm{mg} / \mathrm{ml}$ and $0.025 \mathrm{mg} / \mathrm{ml}$. A. rutus was susceptible to the extract and it growth was inhibited at the concentration less than $0.1 \mu \mathrm{g} / \mathrm{ml}$. Since the inhibitory concentrations against the fungal pathogens were too less, its purified form may be the potential source for controlling fungal pathogens.

\section{Introduction}

Sponges are sessile invertebrates. Hence they were unable to hide or flee from predators and fouling organisms. Sessile organisms depend on chemical defense mechanisms against predator animals and also against pathogens (Gorajana et al., 2005). They protect themselves by secreting chemical substances as secondary metabolite such as antibiotics, and antifouling compounds. Sponges are said to be an excellent source for production of variety of substances. Different kinds of microbes are associated with sponges and are species specific (Imhoff, 2004). Associated microbes are responsible for theses production of variety of secondary metabolites secreted by the host organisms. Microorganisms associated with host organisms contribute the integrity of their 
host and defense by secreting biologically active compound like polypeptides, and alkaloids (Proksch et al., 2002). Actinomycetes are one group of bacteria associated with sponges. They gram positive, filamentous and are potential source for the production of bioactive substances that are medically and industrially important. Nocardia brasilensia produces antibacterial substances against the fish pathogens Vibrio damsel (Takahashi and Omura, 2002). Streptomyces species are greater source for producing antibiotics, antitumor, immunosuppressive agent and enzymes. Streptomyces chibaensis produces quinine related antibiotics, 1-Hydroxy-1norvesistomycin which acts cytotoxic against the cell line Vi2, HMO2-gastric adenocarcinoma1. Many researchers reported the association of actinomycetes with sponges like Great Barrier Reef sponge Rhopalocides odarobile (Webster et al., 2001). Mediterranean sponges, like Aplysina aerophob and Theonella sweinhoehi (Hentschel et al., 2002). Sponges associated actinomycetes like Streptomyces sp., and Altermonas sp., produce antibiotic and therapeutically important compounds with diverse biological activities. Actinomycetes associated with the sponge Hyrtios altum produce antibacterial compounds. Trisisindolins inhibited the growth of $E$. coli at the concentration of $10 \mu \mathrm{g} / \mathrm{disc}$. Streptomyces sp. associated with Dendrilla nigra, produce compounds which, inhibited the growth of Micrococcus leuteus at the concentration of $44 \mu 1 / \mathrm{ml}$. Based on the above information it was understood that sponges and sponges associated actinomycetes are the potential source for the production of bioactive compounds that show different biological activities especially antibacterial and antifungal activity. The purpose of the present investigation is to isolate and identify high antibacterial activity showing actinomycetes associated with marine sponges and to determine their antibacterial and antifungal activity against human bacterial and fungal pathogens.

\section{Materials and Methods}

Sponges were collected from Sangumal at Rameswaram island, Ramanathapuram District, Tamil Nadu state India during May, 2018. Sponges were collected at the depth of 10 meters by the fishermen and identified by experts, using specimen available at Central Marine Fisheries Research Institute, Mandapam, Ramanathapuram district, Tamil Nadu, India. They are identified as Acanthella klethra, Theonella cylindrica, Helicona sp, Auletta sp, and Callyspongia sp. by Dr. Gerold Wilson, Assistant Professor of Marine Sciences, Kings Institute.

Samples of sponges were kept in the pre sterilized sampling bottles containing sterile seawater and kept in the ice box. Collected samples were brought to the laboratory and analyzed within $4 \mathrm{hr}$ after collection. One gm of sponge was taken from each sponge and rinsed with sterile distilled water thrice and ground with nine $\mathrm{ml}$ of phosphate buffer $(\mathrm{pH}$ 7.0) and serially diluted. Dilution of each sponge extract was used for the isolation of sponges associated actinomycetes using Starch Casein Agar (pH 7.2). The medium was supplemented with Nalidixic acid $20 \mu \mathrm{g} / \mathrm{ml}$, Nystatin $25 \mu \mathrm{g} / \mathrm{ml}$ and Cycloheximide $100 \mu \mathrm{g} / \mathrm{ml}$. $0.1 \mathrm{ml}$ of diluted sample was spread over the starch casein agar medium using sterile ' $\mathrm{L}$ ' rod. The plates were incubated at $28^{\circ} \mathrm{C}$ for 7 days. To screen the high efficiency antagonistic activity showing actinomycetes, cross streak method was followed, using modified nutrient agar medium (Peptone $0.57 \%$, Glucose $0.5 \%$, Beef extract $0.3 \%, \mathrm{NaCl} 0.5 \%, \mathrm{pH} 7.2 \pm 0.2$ ). Antagonistic activity showing actinomycetes were identified based on their morphological, physiological and biochemical tests. 
Identified organisms were used to evaluate the antibacterial, antifungal activity and to determine their MIC value for bacterial and fungal pathogens.

Antagonistic activity showing actinomycetes were grown in yeast extract malt extract broth ( $\mathrm{pH} 6.2 \pm 0.2$ ). Broth inoculated with actinomycetes was incubated at $28^{\circ} \mathrm{C}$ for 3-5 days. After incubation period, $20 \mathrm{ml}$ cultures were transferred to $1000 \mathrm{ml}$ of Glycerol Asparagines broth (Glycerol 1\% Asparagine $0.1 \%, \mathrm{KHPO} 0.1 \%, \mathrm{NaCl} 0.5 \%$ and $1 \mathrm{ml}$ of each trace element solution of FeSO $0.1 \%$ and MgSO7HO, $0.1 \%$ ) containing. Flask was incubated at room temperature under continuous shaking for 7 days.

After incubation period broth was adjusted to $\mathrm{pH} 5$ with $1 \mathrm{~N} \mathrm{HCl}$ and centrifuged at 8000 rpm for 10 minutes to remove the mycelial mats and further filtered through membrane filter $(0.45 \mu \mathrm{m})$ to get cell free extract. The supernatant was collected and kept in the separatory funnel. Equal volume of ethyl acetate was added to the supernatant and shake well and the ethyl acetate layer was separated which contained bioactive compounds. This process was repeated thrice to completely extract the bioactive compounds present in the culture broth. Ethyl acetate extract was concentrated in a vacuum evaporator at $40^{\circ} \mathrm{C}$. As a result a yellowish brown residue was obtained. $20 \mathrm{mg}$ of crude extract dissolved in $1 \mathrm{ml}$ of $20 \%$ DMSO, which served as a stock solution. This crude extract solution was used further, to determine antibacterial activity. $10 \mu 1$ of the crude extract solutions were added with sterile paper discs (6mm diameter, Himedia Company, Chennai) aseptically and air dried.

\section{Antibacterial activity of the extract by agar diffusion method}

Antibacterial activity of the extract derived from culture broth of Streptomyces sp. was determined by using the method of agar diffusion described by Bauer et al., (1966). After complete drying, crude extract was used for evaluating anti-bacterial activity. Bacterial pathogens were cultured individually and aseptically in nutrient broth at $37^{\circ} \mathrm{C}$ for $24 \mathrm{hr}$. $0.1 \mathrm{ml}$ of each culture (corresponding to 10 $\mathrm{CFU} / \mathrm{ml}$ ) was placed on Muller-Hinton agar plates and spread throughout the plates by spread plate method. Disc containing the extract was kept on the petriplate containing respective pathogen culture and the plate was incubated at $37^{\circ} \mathrm{C}$ for $24 \mathrm{~h}$. Diameter of the inhibition zone formed around the disc was measured in mm. Disc containing $10 \mu \mathrm{l}$ of $20 \%$ DMSO solution used as negative control and chloramphenicol antibiotic disc (30 mcg/disc) used as positive control.

\section{Antifungal activity of the crude extract of Streptomyces spp. was determined by agar diffusion method (Barry and Thornsberry, 1991)}

An agar diffusion method (Barry and Thornsberry, 1991) was used for evaluating the antifungal activity. Potato Dextrose Agar medium was used for testing the antifungal activity of the extract. The test fungi were cultured in Potato Dextrose broth at room temperature for $24 \mathrm{~h}$. After incubation period, a small amount of fungal culture was transferred into $2.0 \mathrm{ml}$ sterile $0.9 \%(\mathrm{w} / \mathrm{v})$ $\mathrm{NaCl}$. The turbidity of the fungal suspensions was measured at $625 \mathrm{~nm}$ with a spechtrophotometer (UV-Visible Spechtrophotometer, Pharmacia LKB Biochrom 4060 Uppsala, Sweden). The suspensions were diluted to reach an absorbance of 0.1 at $625 \mathrm{~nm}$.

Two hundred fifty microliters of the suspensions were spread evenly on the Petri dishes. Sterile, standardized Whatmann filter papers $(\varnothing=6 \mathrm{~mm})$ containing $200 \mathrm{ml}, 50$ $\mathrm{mg} / \mathrm{ml}$ extracts, and the antibiotics were placed equidistantly on the Petri dishes. Prior 
to incubation in the dark at $+35^{\circ} \mathrm{C}$, the Petri dishes were kept at $+4{ }^{\circ} \mathrm{C}$ for $1 \mathrm{~h}$ to promote the diffusion of the extract into the agar. All the species were incubated at room temperature for 24 and $48 \mathrm{~h}$. The diameter of the clear inhibition zones that had formed around the filter papers was measured. Methanol was used as a negative control. All the tests were made in triplicate.

\section{Minimum Inhibitory Concentration (MIC) determination}

MIC value for bacterial and fungal pathogens was determined by two fold dilution method using 96 well microtitre plate (Eloff et al., 1988). From the stock solution a twofold serial dilution was made in 96 well containing microtitre plate. Two hundred microlitre of crude extract solution was added to well A. $100 \mu \mathrm{l}$ of sterile distilled was added to well B to well $\mathrm{H}$. $100 \mu \mathrm{l}$ of the extract taken from well $\mathrm{A}$ and added to well $\mathrm{B}$ and mix thoroughly. $100 \mu$ l of diluted extract was taken from the well $\mathrm{B}$ and added to the well $\mathrm{C}$ and mixed well. This process was continued till the well $\mathrm{H}$. After through mixing of the content in the well $\mathrm{H}, 100 \mu \mathrm{l}$ was taken and discarded. This brought the final volume in each well to $100 \mu 1$, i.e., the first of the two fold dilution. This procedure was followed in all the wells in the remaining rows. Column from 1 to 7 was used to determine the MIC value of the extract for different pathogens. Well 10 used for positive control (culture plus chloramphenicol), well 11 used as negative control (culture plus 20\% DMSO solution) and well 12 used as growth control (bacterial/fungal culture). 100 $\mu 1$ of bacterial culture (24h old)/ fungal spore suspension was added from the well $\mathrm{A}$ to $\mathrm{H}$. This brings volume of each well to $200 \mu 1$, i.e., second of two fold dilution. Microtitre plate was covered with sterile aluminium foil and incubated at $37^{\circ} \mathrm{C}$ for $24 \mathrm{~h}$. After incubation period, $50 \mu \mathrm{l}$ of $0.2 \%$ Idonitro tetrazolium chloride solution (INT) was added to each well and the plate was incubated further 30 minutes at $37^{\circ} \mathrm{C}$. Growth was indicated by red colour change of the solution and read visually. The MIC was determined as the minimum concentration at which growth was inhibited, i.e., no colour change was visible.

\section{Results and Discussion}

Out of 22 actinomycete isolates, isolate no. 16, showing antagonistic activity against bacterial pathogens, was identified by morphological, physiological tests and Gram's staining. Based on this, isolate no. 16 was identified as Streptomyces sp. The results of the present investigation showed that the crude extract of Streptomyces sp actively inhibited growth of both gram positive bacteria and gram negative bacteria. Among gram negative bacteria $E$. coli and $P$. aeruginosa were susceptible to the crude extract of Streptomyces sp. E. coli was highly sensitive to the extract and the diameter of inhibition zone was $25 \mathrm{~mm}$. Inhibition zone produced against $P$. aerogeniosa, $S$. aureus and $B$. subtilis was $20 \mathrm{~mm}$ (Table 1). $K$. pneumoniae, $P$. mirabilis, $E$. aerogens, Citrobacter sp., S. typhi, and S. paratyphi B were resistant to the extract (Table 1). MIC value for both the bacterial and fungal pathogens were determined by microtitre plate. The results of the MIC value determination showed that fungal pathogens were more susceptible than bacteria tested. The MIC of the crude extracts against the fungal pathogens ranged from $0.015 \mathrm{mg}$ to $0.025 \mathrm{mg} / \mu \mathrm{l}$, whereas for bacterial pathogens it was $2 \mathrm{mg} / \mathrm{ml}$ (Table 2 and 3). The crude extract derived from Streptomyces $\mathrm{sp}$, inhibited the growth of $C$. albicans, Zynomonas sp., A. niger and A. rutus, whereas A. flavus and A. fumigatus were resistant to the extract. Among the fungal pathogens $A$. rutus was more susceptible and its growth was inhibited at the concentration of less than $1 \mu \mathrm{g} / \mu \mathrm{l}$. The extract inhibited the 
growth of A. niger and Zynomonas sp at the followed by $C$. albicans whose growth was concentration of $0.062 \mathrm{mg} / \mathrm{ml}$ and it is inhibited at the concentration of $0.025 \mathrm{mg} / \mathrm{ml}$.

Table 1 Antibacterial activity of ethyl acetate extract of the marine sponges associated Streptomyces sp.

\begin{tabular}{|c|c|c|}
\hline \multirow[b]{2}{*}{ Name of the bacteria } & \multicolumn{2}{|c|}{ Inhibition zone diameter in $\mathrm{mm}$} \\
\hline & $\begin{array}{c}\text { Positive control } \\
\text { Chloramphenicol } \\
\text { (30mcg/disc) }\end{array}$ & $\begin{array}{c}\text { Crude ethylacetate } \\
\text { extract }(10 \mu 1 / \text { disc }) \\
\text { Mean } \pm \text { SD }\end{array}$ \\
\hline E. coli & 14 & $25 \pm 0.6$ \\
\hline K. pneumonia & 9 & ND \\
\hline P. mirabilis & 15 & ND \\
\hline P. aeruginosa & 11 & $20 \pm 0.4$ \\
\hline S. typhi & 11 & ND \\
\hline S. paratyphi B & 10 & ND \\
\hline E. aerogens & 10 & ND \\
\hline Citrobacter sp & 11 & ND \\
\hline B. subtilis & 12 & $20 \pm 0.5$ \\
\hline S. aureus & 10 & $20 \pm 0.6$ \\
\hline
\end{tabular}

Table.2 Minimum Inhibitory Concentration of (MIC) crude extract of Streptomyces sp. on bacterial pathogens

\begin{tabular}{|l|l|}
\hline Name of the bacteria & MIC concentration $(\mathrm{mg} / \mathrm{ml})$ \\
\hline E. coli & $0.2 \mathrm{mg} / \mathrm{ml}$ \\
\hline P. aeruginosa & $0.2 \mathrm{mg} / \mathrm{ml}$ \\
\hline B. subtilis & $0.2 \mathrm{mg} / \mathrm{ml}$ \\
\hline S. aureus & $0.2 \mathrm{mg} / \mathrm{ml}$ \\
\hline
\end{tabular}

Table.3 Antifungal activity of crude extract of Streptomyces sp. on fungal pathogens

\begin{tabular}{|l|l|}
\hline Name of the fungi & Inhibitory zone diameter (in $\mathrm{mm}$ ) \\
\hline Candida albicans & $\mathbf{2 1}$ \\
\hline Zynomonas sp & $\mathbf{2 0}$ \\
\hline Aspergillus niger & $\mathbf{2 3}$ \\
\hline Aspergillus rutus & $\mathbf{2 5}$ \\
\hline
\end{tabular}

Table.4 Minimum inhibiting concentration (MIC) of crude extract of Streptomyces sp. on fungal pathogens

\begin{tabular}{|l|l|}
\hline Name of the fungi & MIC value (mg/ml) \\
\hline Candida albicans & $0.025 \mathrm{mg} / \mathrm{ml}$ \\
\hline Zynomonas sp & $0.06 \mathrm{mg} / \mathrm{ml}$ \\
\hline Aspergillus niger & $0.06 \mathrm{mg} / \mathrm{ml}$ \\
\hline Aspergillus rutus & $0.015 \mathrm{mg} / \mathrm{ml}$ \\
\hline
\end{tabular}


In the present investigation 22 actinomycete isolates were isolated from sponges. Many researchers have isolated actinomycetes from sponges. Schippers et al., (2002), isolated Nocardiopsis alkaliphila and Streptomyces microflavus from alkaline environment. Actinomycetes were isolated from sponges such as Craniella austraiensis ( $\mathrm{Li}$ et al., 2006), Rhapaloeides oderabile, Pseudocentina clavata and Candida spongia flabellate (Kim et al., 2004) and from water and sediment (Devi et al., 2006). In the present study it was observed that the crude extract inhibited the growth of both gram positive and gram negative bacteria. Similarly Basilio et al., (2003), and Rath et al., (2005), also reported the inhibitory effect of ethyl acetate extract of Streptomyces sp. on both gram positive and gram negative bacteria. In the present study it was observed that Streptomyces sp. exhibited higher antifungal activity than antibacterial activity. Similarly Devi et al., (2006), also reported that actinomycetes isolated from water and sediments showed higher antifungal activity than antibacterial activity. Buchanan et al., (2005), reported Saline spore strain associated with sponges showed both antibacterial and antifungal activity. In the present study also even though crude extract derived from Strepotmyces sp. inhibited the growth of both gram positive and gram negative bacteria it highly inhibited the growth of fungal pathogens.

The results of the present study showed that $K$. pneumoniae, P. mirabilis, E.aerogens, Citrobacter sp, S. typhi and S. paratyphi B were resistant to the crude extract of Streptomyces sp. Normally it was observed that $P$. aeroginosa, Klebsiella sp. and S. typhi were able to grow in some antibiotics and their resistance to more antibiotics has also keen of medical concern (Tortora et al., 2002). The results of the present study revealed that Streptomyces $\mathrm{sp}$ secretes antibiotic substance that inhibited the growth of human fungal pathogens (Table 3). Crude extract derived from eighty three percent of actinomycetes isolated from Sagamy Bay were found to be antifungal (Okami and Okazaki, 1972). Many microorganisms isolated from marine environment exhibited antifungal activity against Aspergillus niger but not against Candida albicans. In contrast, the present study showed that Streptomycetes sp inhibited not only $A$. niger but also Candida albicans, Zynomonas sp. A. rutus with the MIC value ranging from $0.015 \mu \mathrm{g} / \mathrm{ml}$ to $0.025 \mu \mathrm{g} / \mathrm{ml}$ (Table 4). The present investigation was well coinciding with study of Nagai et al., (2002), and Kokare et al., (2004). They reported that Streptomyces sp associated with sponges and isolated from marine sediments inhibited the growth of Candida albicans, Crytococcus neoformans and Aspergillus fumigatus with the MIC ranging from $2 \mu \mathrm{g}$ to $16 \mu \mathrm{g} / \mathrm{ml}$. Among microorganisms, especially Streptomyces sp is proved to be as fruitful as their counter parts isolated from terrestrial habitat (Pisano et al., 1989). From the present study, it was observed that marine actinomycetes particularly Streptomyces sp. is a useful and sustainable source of new bioactive natural products.

The bioactive compounds produced by the Streptomyces sp. is a potential source for controlling the growth of Multidrug resistant E. coli, $P$. aeruginosa, S. aureus., B. subtilis, C. albicans, A.. niger, A. rutus and Zynomonas sp, Aspergillus sp. are common contaminants and highly effective antibiotics are required to control the contaminants. Streptomyces sp. isolated from sponges may be useful for controlling such common contaminants.

From this study it was concluded that marine actinomycetes are the potential source for new antibiotics. A novel drug could be synthesized or derived from Streptomyces sp, which could help to control the mutidrug 
resistant E. coli, S. aureus and aflatoxin producing common contaminant of Aspergillus sp.

\section{References}

Barry AL, Thornsberry C 1991. Susceptibility tests: Diffusion Test Procedures. In: Balows A, Hauser WJ, Hermann KL, Isenberg HD, Shamody HJ 1991. Manual of clinical microbiology. 5.ed. Washington, DC: American Society for Microbiology, p. 1117-1125.

Basilio A, Gonzalez I, Vicent M, Gorrochateguri J, Cabella A, A. Gonzalez A, \& O. Genilloud O. 2003. Patterns of antimicrobial activities from soil actinomycetes isolated under different conditions of $\mathrm{pH}$ and salinity. J. Appl. Microbiol. 95: 814-820.

Bauer AW, Kirby WM, Sherris JC, Turk M. 1966. Antibiotic susceptibility by a standardized single disk method. Amer. J. Clin. Pathol. 45: 493-496.

Buchanan GO, Williams PG, Feling RH, Kauffman CA, Jensen PR, Fenical W. 2005. Sporolides A and B: structurally unprecedented halogenate macrolides from marine actinomycete Salinispora tropica Org. Lett. 7: 2731-2734.

Devi NKA, Jeyarani M, Balakrishnan K. 2006. Isolation and identification of marine actinomycetes and their potential in antimicrobial activity. Pak. J. Biol. Sci. 9: 470-472.

Eloff JN. 1988. A sensitive and quick microplate method to determine the minimal inhibitory concentration of plant extracts for bacteria. Planta Medica. 64: 711-713.

Gorajana A, Kurada BVVSN, Peela S, Jangam P, Vinjamuri S, E. Poluri E, Zeeck A. 2005. 1- Hydroxy-1norresistomycin, a New cytotoxic compound from marine actinomycetes from Soda Lake in Africa. Int. J. Syst. Microbial. 47: 788-794.

Hentschel U, Hopke J, Horn M, Friedrich AB, Wagner M, Hacker J, Moore BS. 2002. Molecular evidence for a uniform microbial community in sponges from different oceans. Appl. Environ. Microbiol. 68: 4431-4440.

Imhoff JF. 2004. Sponges associated bacteria: General overview and special aspects of the diversity of bacteria associated with Halichondria panicea. Mar. Mol. Biotech. 69: 7224-7235.

Kim BS, Hom S, Hu Kuong OL, Park SS, Chun J. 2004. Remarkable bacterial diversity in the tidal flat sediments as revealed by 16 s rRNA analysis. Appl. Environ. Microbiol. 14: 205-211.

Kokare CR, Mahadik KR, Kadam SS. 2004. Isolation of bioactive marine actinomyctes from sediments isolated from Goa and Maharastra Coast Lines (West Coast of India). Ind. J. Marine Sci. 33: 248-256.

Li Z, He L, Wu J, Jiang Q. 2006. Bacterial community diversity associated with four marine sponges from SouthChina sea based on $16 \mathrm{~S}$ rRNA DGGE fingerprinting. J. Exp. Mar. Biol. 329: 75-85.

Nagai, K, Kamigiri K, Matsunmoto H, Kawano Y, Yamaoka M, Shimoi Watanabe M, Suzuki K. 2002. YM202204, a new antifungal antibiotic produced by marine fungus Phoma sp. J. Antibiot. 55: 1036-1041.

Okami Y, Okazaki T. 1972. Studies on Marine microorganisms (1) Isolated from the sea. J. Antibiotics. 25: 456460.

Pisano MA, Sommer MJ, Brancacci L. 1989. Isolation of bioactive actinomycetes from marine sediments using rifampicin. Applied. Biotech. 31: 609612. 
Proksch P, Edrada RA, Ebel R. 2002. Drugs from the Sea - Current Status and Microbial Implications. Appl. Microbial. Biotech. 59: 125-134.

Rath JP, Kinsat S, Maier M. 2005. Synthesis of the full-functionalized core structure of the antibiotic abyssomicin C. Org. Lett. 7: 3089-3092.

Schippers A, Boscker K, Willscher S, Sproper C, Schumann P, Kroppenstedt RM. 2002. Nocardiopsis metallicus sp. A Novel metal leaching actinomycetes isolated from alkaline slag dump. Int. J. Syst. Evol. Microbiol. 52: 22912295
Takahashi Y, Omura S. 2003. Isolation of new actinomycetes strains for screening of new bioactive compounds. J. Gen. Appl. Microbial. 49: 141-154.

Tortora GJ, Funke BR, Case CL. 2002. Microbiology $6^{\text {th }}$ Edn. The Benjamin/ Cummings Publishing Company Inc., pp-300, 659-668.

Webster NS, Wilson KJ, Blackall LL, Hill RT. 2001. Phylogenetic diversity of bacteria associated with marine sponges Rhopaloeides odorabile. Appl. Environ. Microbiol. 67: 434444.

\section{How to cite this article:}

Parimala, S., M. Kandhasamy and Chinnasamy, P.S. 2018. Antimicrobial Activity of the Crude Extract Derived from Streptomyces spp. Associated with Sponges. Int.J.Curr.Microbiol.App.Sci. 7(08): 1187-1194. doi: https://doi.org/10.20546/ijcmas.2018.708.133 